\title{
MENGUPAYAKAN KEMBALI EKSISTENSI IDEOLOGI PANCASILA
}

\author{
Efriza \\ Dosen Tetap Program Studi Ilmu Politik di Sekolah Tinggi Ilmu Pemerintahan Abdi \\ Negara (STIP-AN), Jakarta; dan penulis buku antara lain, "Kekuasaan Politik: \\ Perkembangan Konsep, Analisis, dan Kritik," Malang: Intrans Publishing, 2016 \\ Efriza.riza@gmail.com
}

\begin{abstract}
ABSTRAK
Tulisan ini mencoba menganalisis perkembangan realitas perpolitikan dan juga mensikapi upaya pemerintah dalam memantapkan kembali eksistensi Ideologi Pancasila sebagai ideologi bersama. Upaya pemerintah itu juga menunjukkan keinginan memadukan nasionalisme, demokrasi, dan Ideologi Pancasila secara bersama. Kesadaran mengembalikan eksistensi ideologi Pancasila adalah suatu upaya memupuk kesadaran rasa nasionalisme kebangsaan.
\end{abstract}

Kata kunci: Ideologi Pancasila, Nasionalisme, Demokrasi

\begin{abstract}
This paper attempts to analyze the development of thinking and also responds to efforts to re-establish the existence of Pancasila Ideology as a common ideology. The government's efforts also demonstrate the shared desire of nationalism, democracy, and the ideology of Pancasila together. Pancasila ideology's unconscious awareness is an attempt to foster a sense of nationalism.
\end{abstract}

Key words: Pancasila Ideology, Nationalism, Democracy,

\section{A. Pendahuluan}

Ideologi Pancasila yang merupakan kesepakatan dasar dari bernegara yang seyogianya telah dipilih untuk dijalankan sebagai ideologi bersama masyarakat Indonesia kembali diupayakan eksistensinya oleh Presiden Jokowi. Pemerintahan sekarang ini memang sedang mengupayakan kembali eksistensi ideologi Pancasila dengan menekankan semangat nasionalisme dan demokrasi, secara bersamaan dengan ideologi Pancasila.

Ideologi Pancasila setelah runtuhnya Orde Baru, dalam realitasnya bahwa Pancasila mulai dilupakan dalam berbagai aspek kehidupan, termasuk kehidupan bermasyarakat, berbangsa dan bernegara. Lahirnya perilaku politik identitas, konflik bermotif Suku, Agama, Ras, dan Antargolongan (SARA), korupsi di berbagai tingkatan, dan melemahnya keteladanan merupakan bukti menurunnya pemahaman nilai-nilai Pancasila. 
Realitas ini yang menyebabkan timbulnya suatu pertanyaan, Bagaimana ideologi Pancasila menghadapi perkembangan zaman dan arus informasi yang begitu kuat dan deras "menyapu" kehidupan bersama masyarakat Indonesia? Ideologi Pancasila ini seyogianya menjadi Ideologi bersama bangsa Indonesia, mempersatu rasa nasionalisme rakyat Indonesia, dan ideologi Pancasila ini semestinya pula menjiwai dan mensifati perkembangan aspirasi dan kepentingan masyarakatnya. Sehingga, wajar jika Presiden Jokowi teramat bersedih melihat realitas perkembangan saat ini, dengan mengatakan bahwa demokrasi kita adalah demokrasi yang kebablasan dikhawatirkan membuka peluang artikulasi politik yang ekstrem seperti liberalisme, radikalisme, fundamentalisme, sekterianisme, terorisme, serta ajaran-ajaran yang bertentangan dengan ideologi Pancasila, (http://nasional.kompas.com/read/2017/02/22/12031291/jokowi.demokrasi.kita.suda $\underline{\text { h kebablasan). }}$

Penelitian ini dirancang menggunakan pendekatan kualitatif dengan teknik pengumpulan data yang digunakan adalah studi pustaka. Setelah teknik pengumpulan data dilakukan maka data tersebut akan diolah, dianalisis dan dilakukan interpretasi data, sehingga akan menghasilkan suatu temuan atau hasil penelitian yang akan menjawab pertanyaan penelitian yang diajukan, (Haris Herdiansyah, 2010; Sanipah Faisal, 2008).

Dari seluruh proses penelitian ini, penulis beragumen bahwa pemerintahan Jokowi-JK ingin mengembalikan kesadaran untuk menjiwai, mensifati, serta memantapkan kembali ideologi Pancasila sebagai ideologi bersama. Kesadaran mengembalikan eksistensi ideologi Pancasila adalah suatu upaya memupuk kesadaran rasa nasionalisme kebangsaan.

\section{B. Pembahasan}

Ghia Nodia dalam tulisan "Nasionalisme dan Demokrasi," menjelaskan bahwa nasionalisme tidaklah mungkin - tak dapat dipertimbangkan - tanpa ide tentang demokrasi, dan bahwa demokrasi tak pernah ada tanpa nasionalisme. Kedua ide tersebut dipersatukan dalam semacam perkawinan yang rumit, yang satu tak dapat hidup tanpa yang lain, tetapi hidup bersama dalam satu ketegangan yang permanen, (Larry Diamond dan Marc F. Plattner (Eds), 1998: 19).

Di Indonesia kita mengetahui, memahami, dan menghayati hakikat dari Pancasila sebagai ideologi terbuka. Sifat terbuka demokrasi kita dijiwai dan disifati dengan rasa tanggung jawab masing-masing kita terhadap keutuhan dan pengembangan kehidupan bermasyarakat, berbangsa, dan bernegara dengan segala aspek atau dimensinya. Kita pun juga telah memahami bahwa sifat terbuka demokrasi kita, Pancasila bukanlah sesuatu yang baru, bahkan dapat dikatakan sudah melekat di dalam dirinya, (Alfian, 1991: 26). Namun belakangan ini, masingmasing golongan atau kekuatan politik yang ada seringkali mengutamakan dan memperkuat ideologi yang dianutnya daripada apa yang seyogianya menjadi ideologi bersama mereka tersebut, untuk memahami perkembangan kekinian adalah sebagai berikut. 


\section{a. Perkembangan Arus Teknologi dan Informasi}

Perkembangan konsep demokrasi seiring berjalannya waktu telah mengalami perubahan. Jika demokrasi yang awalnya bersifat langsung, saat ini bergeser pada sistem politik perwakilan atau representasi. Dalam perkembangannya, prinsip dasar representasi dikritisi karena sering kali dianggap kehendak warga negara tidak tersampaikan dan kemudian menjadi sebuah kebijakan yang diputuskan oleh pemerintah.

Dengan perkembangan kehadiran internet di tahun 1980-an telah memicu perubahan kehidupan manusia, termasuk berpolitik. Apabila kita telisik lebih lanjut, dengan sifatnya yang interaktif, yang mana semua warga dapat berkomunikasi satu sama lain secara interaktif, serta terjaminnya kebebasan mengeluarkan pendapat, internet dapat dikatakan sebagai media baru dalam demokrasi,(http://www. mediaindonesia.com/index.php/ news/read/73975/demokrasi-digital/2016-10-26\#).

Sayangnya, di era demokrasi digital ini terjadinya polarisasi politik seperti dapat dilihat dalam Pemilihan umum Presiden (Pilpres) tahun 2014, bahkan menjelang Pemilihan Kepala Daerah (Pilkada) DKI tahun 2017 lalu. Kontestasi antara Jokowi dan Prabowo menuju RI 1, serta kasus dugaan penistaan agama yang menyeret calon gubernur Basuki Tjahaja Purnama atau Ahok, adalah contoh eliteelite politik yang berkepentingan memobilisasi massa melalui kampanye di jejaring media sosial. Mereka mampu menggerakkan solidaritas berbasis identitas keagamaan, kedaerahan, sampai preferensi politik tertentu, untuk turun ke jalan.

Di era digital sekarang ini juga seorang presiden ataupun kepala daerah tidak lagi mengandalkan tatap muka langsung. Interaksinya kini bisa berlangsung di media sosial. Dengan pola komunikasi seperti ini, penyampaian kebijakan ataupun program secara tradisional mulai ditinggalkan. Sebab melalui internet pesan akan lebih efektif dan cepat diterima. Publik juga bisa langsung menyampaikan aspirasi, tanpa harus bertemu langsung penguasa. Tetapi, perlu diingat juga bahwa kehadiran media sosial dapat merusak demokrasi jika masyarakat tidak hati-hati dan bijak menggunakannya. Ketidakhati-hatian akan membuat masyarakat mudah termakan berita fitnah (hoax).

Kondisi ini pula yang menyelimuti pemikiran dari Presiden Jokowi yang merespons atas situasi masyarakat dalam perkembangan media baru. Presiden Jokowi mengatakan bahwa demokrasi kita sekarang ini adalah demokrasi yang kebablasan, sehingga membuka peluang artikulasi politik yang ekstrim seperti liberalisme, radikalisme, fundamentalisme, sekterianisme, terorisme, serta ajaranajaran yang bertentangan dengan ideologi pancasila. Situasi ini jika didiamkan bisa memecah belah bangsa kita oleh karena itu menghadapi demokrasi yang kebablasan ini adalah melalui penegakan hukum. Presiden Jokowi kemudian meminta aparat hukum bertindak tegas terhadap setiap pelanggaran yang terjadi, (http://nasional.kompas.com/read/2017/02/2212031291/jokowi.demokrasi.kita.

sudah.kebablasan). Hasilnya adalah penegakkan hukum melalui Kepolisian RI mengklaim penanganan tindak pidana kelompok Saracen berhasil menekan penyebaran ujaran kebencian di Internet. Hampir 50 persen hate spech berkurang di dunia maya, (Koran Tempo, 6 September 2017: 32). 


\section{b. Kultur Demokrasi yang Berubah}

Demokrasi di Indonesia yang bisa diibaratkan seperti "rumah produksi" dan berbiaya tinggi, tetapi telah mengabaikan nilai-nilai ideologis kepartaian dan dalam proses pemilihan umum. Realitas ini telah menyebabkan beberapa politisi di Indonesia terjangkiti virus demagogue, yang mana politisi yang gemar mengadukaduk perasaan masyarakat, biasanya dengan menggunakan isu agama, untuk kepentingan politiknya, daripada mengajak berpikir secara obyektif dalam mencari jalan keluar misalnya menyangkut masalah problematika kesejahteraan masyarakat, memang realitas tak bisa dikesampingkan bahwa politik selalu melahirkan demagogue, namun demagogi mendorong tumbuh suburnya radikalisme. Bahkan, demagogue mengabaikan pengakuan pluralisme dan penerimaan perbedaan, maka ketika Partai Politik atau Pasangan Calon mengemas isu wacana kebencian maka tentu tidaklah sesuai dengan demokrasi yang mengakui pluralisme dan menerima perbedaan, dan tentu demagogue tidak diakui sebagai cara demokratis bahkan ditentang oleh negara-negara demokrasi, dengan lebih tegas di Prancis dijelaskan dengan adanya pepatah bahwa "Le demagogue est le pire ennemi de la democratie" (demagogue adalah musuh terbesar demokrasi), (Haryatmoko, 2003: 111-115).

Dalam kasus di Indonesia belakangan ini isu agama begitu "seksi" untuk digunakan dalam mengupayakan menyerang pasangan kandidat lainnya. Bahkan, beberapa kasus di Indonesia dalam segmentasi sempit dan terbatas saja, isu yang dihembuskan bahwa misalnya, partai politik bisa dianggap membawa kepentingan ideologi komunis atau kepentingan khilafah yang jelas-jelas telah dianggap bertentangan dengan ideologi Pancasila sebagai kesepakatan bersama. Maupun, seorang calon yang akan berkompetisi dalam Pilkada akan dihembuskan isu yang bersifat penggunaan isu agama untuk menjatuhkan salah satu pasangan calon tersebut, fenomena isu agama telah mulai terjadi sejak era reformasi tatkala pencalonan Megawati sebagai Presiden Indonesia, isu yang banyak dihembuskan dan menjadi berita "seksi" di media ketika itu adalah isu yang berkaitan dengan "haram" seorang pemimpin perempuan di Indonesia. Pemberitaan media massa akhirnya terbawa arus lebih cenderung mendukung suara dominan yang menentang kepemimpinan politik perempuan di Indonesia. Upaya menggulingkan Megawati dari kandidat presiden perempuan ketika itu cukup kuat, yang pada akhirnya media massa berhasil membentuk agenda publik untuk memusuhi perempuan menjadi pemimpin politik di Indonesia, inilah kekuatan isu agama dalam ranah gender, (Henry Subiakto, Rachmah Ida, 2014: 188-189).

Realitas penggunaan isu agama tersebut harus diakui juga disumbang oleh perilaku politik dari partai-partai politik saat ini yang hanya mementingkan aspek elektoral semata. Sehingga partai politik tidak lagi mengedepankan seperti sebagai partai integrasi-massa, produk massa menonjolkan jaringan-jaringan kelas dan struktur penggolongan, telah mengubah dirinya menjadi suatu partai yang disebut oleh Otto Kichheimer sebagai catch all.

Partai-partai politik telah meninggalkan usaha-usaha pengkaderan massa secara intelektual dan moral, partai politik telah beralih ke arena pemilihan umum dan berusaha menukar efektivitas dan kedalaman sedikit anggota dengan usaha meraih audiens yang lebih luas dan kemenangan dalam pemilihan umum (Ichlasul Amal (Eds), 1996: 45). 
Merosotnya citra partai politik itu, tentu akan berakibat buruk terhadap opini publik yang merupakan kekuatan politik penting dalam demokrasi. Opini publik yang buruk niscaya akan membuat citra demokrasi juga merosot. Sosiolog Anthony Giddens dalam Arifin menyatakan, bahwa kepercayaan terhadap demokrasi, memang menurun. Namun kepercayaan publik yang menurun itu, bukan pada demokrasi dalam tataran konsep, melainkan kepercayaan itu merosot terhadap aktor politik atau politisi, (Anwar Arifin, 2006: 202-203). Aktor politik atau politisi itu, tentu tidak dapat dipisahkan dengan partai politik yang mengusungnya. Bahkan, hasil kajian Lili Romli yang mengantarkannya menjadi Profesor Riset LIPI pada 20 Desember 2017 lalu menyatakan bahwa, institusional partai politik masih lemah di pascareformasi karena faktor absennya ideologi partai, munculnya kepemimpinan personal/klientelistik, konflik internal partai, dan temuan baru yaitu pragmatisme politik, (Lili Romli, 2017: 21).

Memang berbagai hasil survei telah berkali-kali dirilis dan hasilnya tetap sama, dan hasil ini harus dijadikan tantangan bagi partai politik untuk memperbaiki citra diri bahwa partai politik telah dipersepsi publik sebagai hulu semua permasalahan bangsa. Meski demikian, menurut Inggrid van Biezen bahwa, merosotnya citra partai politik itu, tidak berarti bahwa partai politik itu tidak lagi relevan dalam kehidupan demokrasi sekarang ini, (Anwar Arifin, 2006: 202-203).

Sehingga realitas di atas, jika kita melihat perkembangan kebangsaan saat ini, maka dapat dikatakan penyumbang dari kemerosotan nasionalisme ini bukan dari rasa keetnikan yang berlebihan, melainkan dari tiadanya pengungkapan politik yang sehat bagi perasaan kebangsaan. Hal ini disebabkan, rakyat tidak memiliki prestasi politik atau kelembagaan yang dapat dibanggakan, mereka malah dapat membanggakan rasa identitas berdasarkan agama, ras, bahasa, atau budaya yang diwarisinya, (Larry Diamond dan Marc F. Plattner (Eds), 1998: 19).

\section{c. Perubahan Kebersamaan dan Keberagaman}

Melihat realitas bahwa Indonesia merupakan negara kepulauan yang terdiri lebih dari 13 ribu pulau yang membentang dari Sabang sampai Merauke. Masingmasing pulau dihuni oleh komunitas masyarakat yang memiliki karakteristik sosial, budaya dan bahkan nilai dan keyakinan serta agama yang berbeda. Hal ini tercermin dari 300 lebih kelompok etnis yang ada di Indonesia sehingga Indonesia dikenal sebagai bangsa yang memiliki keragaman budaya terbanyak. Dari berbagai macam suku bangsa di Indonesia dengan beragam hasil kebudayaannya menjadikan tantangan dalam menciptakan sebuah integrasi sosial. Dengan struktur sosial yang sedemikian kompleks, sangatlah terbuka bagi Indonesia untuk selalu menghadapi konflik antaretnik, kesenjangan sosial, dan sulit membangun integrasi secara tetap. Oleh karena itu, perlu adanya suatu penanaman konsep kebersamaan dalam keberagaman, (http://www.kompasiana.com/ tnfinspiratif/pluralisme-budaya-dalamnation-buildingdiindonesia_552a7327f17e 61210fd623af).

Memahami perkembangan kebersamaan dalam keberagaman di Indonesia saat ini telah menjadi sesuatu yang given. Meski begitu, dengan kompleksitas yang sekarang maka masyarakat membutuhkan keberagaman yang berbeda dengan sebelumnya. Keberagaman agama, misalnya, menjadi satu isu yang intens dibahas dan diperdebatkan sekarang ini. Persoalan isu agama, apabila dilihat keberagaman 
agama dalam konteks Indonesia bukan sesuatu hal yang baru, tetapi melihat proporsi bangsa Indonesia saat ini telah berubah, misalnya dulu Islam memang menjadi mayoritas penuh, dan sekarang dalam sisi-sisi yang lain ada kebijakan-kebijakan seperti mengakui agama Konghucu, yang di masa Orde Baru tidak diakuinya agama diluar dari lima agama seperti, Islam, Kristen Katolik, Buddha, Hindu dan Kristen Protestan, (Wawancara, Erna Ermawati Choatim, 2017).

Kebijakan-kebijakan pemerintah yang melarang adanya agama baru di masa Orde Baru, saat bergulirnya reformasi kebijakan tersebut dianulir oleh Pemerintahan Presiden K.H. Abdurrahman Wahid dengan menerbitkan Keputusan Presiden Nomor 6 Tahun 2000 tentang Pencabutan Instruksi Presiden Nomor 14 Tahun 1967 Tentang Agama, Kepercayaan, dan Adat Istiadat Cina, (http://wisnu. blog.uns.ac.id/2011/03/ 10/pengakuan-agama-khonghucu-di-indonesia/). Dengan mengakui agama Konghuchu sebagai agama resmi di Indonesia, ini menunjukkan pengakuan satu agama baru lagi di Indonesia kemudian menjadikan proporsi keberagaman agama serta populasinya turut berubah.

Ini yang tidak disadari oleh kelompok yang mayoritas maupun kelompok yang minoritas, masih terkesan bahwa seolah-olah adanya suatu mayoritas yang penuh, sehingga dia memunyai otoritas yang penuh pula untuk "mengatur." Maksudnya adalah mengatur ataupun memonopoli kelompok-kelompok yang minoritas, yang dilakukan oleh kelompok yang mayoritas dalam institusi agama. Sementara proporsinya sekarang telah berubah, yang mana proporsi ini jika kita berbicara dalam konteks politik menggambarkan peta-peta kekuatan dan posisinya pun turut mengalami perubahan. Bagaimana sesungguhnya tarik menarik dalam konteks perubahan-perubahan ini, semestinya perlu ditelaah lebih lanjut sehingga kita bisa mengakui atau merumuskan model atau pola keberagaman (pluralisme) apa yang paling relevan untuk diterapkan saat ini, tetapi sampai saat ini masih belum dilakukan atau malah mungkin belum dimengerti.

Sehingga terjadi seperti konsep toleransi dan intoleransi yang saat ini menjadi salah kaprah. Jadi ketika misalnya, saya sepakat dengan kelompok tertentu dianggap tidak toleran, cara pandang seperti itu adalah keliru. Contoh realitas ini adalah ketika kedua kubu terjadi tarik menarik yang cukup kuat dalam merepresentasikan dinamika politik di Indonesia pada Pilkada DKI Jakarta 2017 lalu, seperti ada kubu Basuki Tjahaja Purnama yang merepresentasikan kelompok minoritas dan kelompok Anis Baswedan (pesaing di Pilkada) yang merepresentasikan kelompok mayoritas, hal mana kelompok mayoritas ini menganggap kelompok minoritas yang mendukung Ahok dianggap intoleran atau yang sebaliknya terjadi, seperti itu realitasnya.

Memang sah-sah saja secara ideologis orang memunyai acuan-acuan yang berdasarkan keyakinannya, tak hanya melulu alasan ideologis. Namun, apabila ada tindakan memprovokasi orang untuk mengikuti ideologi atau pilihannya, maka itulah yang salah. Kasus tersebut adalah hal-hal yang kecil dan sederhana, tetapi kita belum dapat menempatkannya dalam konteks atau pola keberagaman seperti apa yang relevan untuk saat ini. Dan, tantangan kebangsaan sekarang ini adalah menempatkan kembali konsep keberagaman itu secara utuh di dalam perubahan transformasi masyarakat pada era sekarang. 
Dengan perubahan kelembagaan, misalnya, dulu apabila berbicara tentang Islam, institusi yang mewakili Islam dapat disebutkan seperti Muhammadiyah dan Nahdlatul Ulama (NU), serta Persis (Persatuan Islam), dll. Tetapi saat ini bila berbicara tentang Islam dari sisi institusi agama akan lebih variatif, seperti dalam kelompok Islam itu sendiri sudah mulai ada perubahan peta kekuatan kelembagaan maupun institusi. Jadi, ketika ada perubahan proporsi tersebut maka ini juga menggambarkan adanya perubahan peta kekuatan di tengah-tengah umat Islam sendiri, (Wawancara, Erna Ermawati Choatim, 2017).

\section{d. Upaya Membangun Kembali Semangat Nasionalisme}

Pancasila sebagai dasar dan ideologi negara merupakan kesepakatan politik para founding fathers ketika negara Indonesia didirikan. Tetapi, secara historis, dalam konteks pendidikan nasional, memang tidak dapat dimungkiri bahwa Pancasila sebagai ideologi bangsa mengalami fluktuasi tafsiran dari setiap Orde, bukan hanya masa Orde Baru yang dianggap paling getol memberikan tafsir, melainkan juga sudah dimulai sejak masa pemerintahan Presiden Soekarno pada masa Orde Lama.

Namun, tetap saja Pancasila tidak melekat pada Jiwa dan darah bangsa Indonesia, terutama para remaja. Oleh karena itu, dalam sambutannya di depan sidang MPR RI pada 1 Juni 2011 dalam rangka memperingati Pidato Bung Karno 1 Juni 1945, mantan Presiden B.J. Habibie menyampaikan bahwa, "sejak reformasi 1998, Pancasila seolah-olah tenggelam dalam pusaran sejarah masa lalu yang tak lagi relevan untuk disertakan dalam dialetika reformasi. Pancasila seolah hilang dalam memori kolektif bangsa. Pancasila semakin jarang diucapkan, dikutip, dan dibahas dalam konteks kehidupan ketatanegaraan, kebangsaan maupun kemasyarakatan. Pancasila seperti tersandar di sebuah lorong sunyi justru di tengah denyut kehidupan bangsa Indonesia yang semakin hiruk-pikuk dengan demokrasi dan kebebasan berpolitik," (Undang A. Kamaluddin dan Muhammad Alfan, 2015: 161).

Padahal sebagai pandangan hidup bangsa dan dasar negara Republik Indonesia, Pancasila harus dihayati dan diamalkan secara nyata untuk menjaga kelestarian dan keampuhannya demi mewujudkan tujuan nasional serta cita-cita bangsa Indonesia. Hal ini dikarenakan nilai-nilai yang ada dalam Pancasila merupakan wujud dari budaya dan tradisi bangsa Indonesia yang melekat dan dapat dilaksanakan, (Undang A. Kamaluddin dan Muhammad Alfan, 2015: 161-162).

Harus diakui aktualisasi paling jelas dan paling brilian dari budaya nasional Indonesia adalah Pancasila dan UUD 1945 (sekarang UUD NRI 1945). Pancasila mengandung sejumlah nilai pokok yang tercakup dalam unsur-unsur budaya lainnya, yang selanjutnya diangkat ke tingkat yang menyatukan berbagai unsur budaya lainnya. Sebab itulah Pancasila dan UUD 1945 semestinya menjadi faktor integratif yang sangat instrumental dalam kehidupan berbangsa, bernegara, dan berbudaya di Indonesia, (Azyumardi Azra, 2002: 41).

Saat ini masing-masing golongan atau kekuatan politik yang ada lebih mengutamakan dan memperkuat ideologi yang dianut daripada apa yang seyogianya menjadi ideologi bersama mereka sebagai kesatuan berbangsa dan bernegara yaitu Ideologi Pancasila. Karena masing-masing golongan atau kekuatan politik menjadi 
terobsesi dengan ideologinya masing-masing, maka hal itu selanjutnya merasang mereka untuk bersikap dan bertingkah laku a priori terhadap golongan atau kekuatan politik lain karena mereka merasa telah menemukan kebenaran mutlak dengan ideologi yang menjadi obsesinya itu. Masing-masing bersikap dan bertingkah laku memonopoli kebenaran, dan oleh karena itu bukan saja tak dapat menerima pandangan atau pendapat golongan atau kelompok lain, tetapi juga cenderung untuk mencurigainya. Dari situ tentu lahir dan berkembangnya suasana kehidupan politik yang sangat diwarnai oleh pertentangan ideologi, rasa saling curiga dan bermusuhan yang terus meningkat, beserta primodialisme yang semakin menguat. Aspirasi dan kepentingan golongan sangat diutamakan oleh karena itu tidak memungkinkan mereka untuk mencapai konsensus dalam merumuskan apa yang seyogianya menjadi aspirasi dan kepentingan nasional. Disadari ataukah tidak, secara berangsur-angsur mereka menuju ke dalam pelukan anarkisme. Akhirnya, masing-masing mau menang sendiri, (Alfian, 1991: 9-10).

Melihat perkembangan pemerintahan sekarang ini, jelas bahwa Jokowi teramat bersemangat untuk memperkuat Pancasila sebagai jiwa bangsa Indonesia. Seperti disampaikannya Presiden Jokowi saat memberikan sambutan pada Kongres Pancasila Ke-9 yang dihelat di Kampus Universitas Gadjah Mada, Yogyakarta, Sabtu (22/7/2017). Presiden Jokowi mengatakan bahwa, "Kita berkumpul di sini untuk komitmen yang sama, untuk semangat yang sama, yaitu semangat untuk memperkuat Pancasila sebagai jiwa bangsa kita, sebagai jiwa raga kita, dan sebagai cara hidup berbangsa dan bernegara," (http://kabar24.bisnis.com/read/20170722/15/673935/ jokowi-minta-kobarkan-terussemangat-memperkuat-pancasila).

Memang upaya kembali untuk kita mengakui dan menerima terhadap Pancasila saja belum cukup. Perkataan dan tindakan elite politik dan masyarakat umumnya hendaklah sesuai dengan cita-cita dan apa yang digariskan Pancasila. Pancasila sebagai ideologi negara memang memiliki peranan besar dalam mewujudkan integrasi nasional. Keutuhan Negara Kesatuan Republik Indonesia (NKRI) selama ini diikat oleh semangat Nasionalisme sebagai tali pengikat dalam menjaga keutuhan NKRI tersebut. Namun, menghadirkan nasionalisme - jika dilakukan tanpa memperbarui pemaknaan dan penerjemahan ideologi Pancasila dengan realitas kekinian - malah akan menambah berbagai persoalan. Meski telah dipahami bahwa nasionalisme bangsa Indonesia dalam konteks Pancasila berifat "majemuk tunggal" (bhineka tunggal ika), namun sejarah panjang menjadi Indonesia dipenuhi oleh trauma historis bahwa, konstruksi "musuh-musuh imajiner" yang dapat dikenakan pada orang atau kelompok manapun yang hendak disingkirkan. Identitas kecinaan vis a vis (keturunan) "pribumi," kekristenan sebagai "agama kolonial," kaum penghayat kepercayaan sebagai kelompok "belum beragama" dsb, merupakan "hantu-hantu" yang terus menerus menggelisahkan keamanan kita. Pada titik itu, tidak salah jika upaya membangun tatanan ke-Indonesia-an yang nir-kekerasan bagaikan upaya mempertahankan suatu utopia (politics of dream), (Trubus P. Rahardiansah, 2006: 218-282). 


\section{Simpulan}

Di awal tulisan telah dijelaskan bahwa pemerintahan sekarang ini sedang mengupayakan dalam memadukan antara nasionalisme, demokrasi, dan ideologi Pancasila. Tiga sudut pandang ini coba dilekatkan kembali oleh Presiden Jokowi bahwa ideologi Pancasila merupakan kesepakatan dasar dari bernegara yang seyogianya telah disepakati dan dijalankan sebagai ideologi bersama.

Sepertinya Presiden Jokowi pun menyadari bahwa ketika suatu negara tidak mampu menjinakkan aspek keetnikan dan nasionalismenya maka dapat mengarahkan kepada rasisme, anarkisme, dan radikalisme. Namun jika dilihat berdasarkan realitas di atas bahwa manifestasi sisi buruk nasionalisme ini bukan disumbang oleh rasa kebanggaan atas keetnikan yang berlebihan, tapi melainkan dari tiadanya pengungkapan politik yang sehat bagi perasaan kebangsaan.

Tampaknya, rakyat tidak memiliki prestasi politik atau kelembagaan yang dapat dibanggakan, mereka malah dapat membanggakan rasa identitas berdasarkan agama, ras, bahasa, atau budaya yang diwarisinya, (Larry Diamond dan Marc F. Plattner (Eds), 1998: 19). Memang upaya kembali untuk kita mengakui dan menerima terhadap Pancasila saja belum cukup. Perlu disadari bahwa tantangan kebangsaan sekarang ini adalah mengupayakan penempatan kembali konsep keberagaman secara utuh di dalam perubahan transformasi masyarakat, dan disertai pula kesadaran untuk selarasnya perkataan dan tindakan elite politik dan masyarakat umumnya terhadap semangat, cita-cita dan apa yang digariskan Pancasila sehingga akan mewujud dalam upaya menuju keberhasilan membangun sistem politik demokrasi Pancasila.

\section{Daftar Pustaka}

Alfian, Komunikasi Politik dan Sistem Politik Indonesia, Jakarta: Gramedia Pustaka Utama, 1991.

Arifin, Anwar, Pencitraan dalam Politik (Strategi Pemenangan Pemilu dalam Perspektif Komunikasi Politik), Bandung: Pustaka Indonesia, 2006.

Azra, Azyumardi, Reposisi Hubungan Agama dan Negara: Merajut Kerukunan Antarumat, Jakarta: Kompas, 2002.

Diamond, Larrry, dan Plattner, Marc F., Nasionalisme, Konflik Etnik, dan Demokrasi, Bandung: ITB, 1998.

Faisal Sanipah, Metodelogi Penelitian Kualitatif: Dasar-dasar dan Aplikasi, Malang: YA3 Malang, 1990.

Herdiansyah, Haris, Metodelogi Penelitian Kualitatif untuk Ilmu-ilmu Sosial, Jakarta: Salemba Humanika, 2010. 
Kamaluddin, Undang A., dan Alfan, Muhammad, Dinamika Politik di Indoesia: Perjalanan Politik Sejak Orde Lama Hingga Reformasi, Bandung: Pustaka Setia, 2015.

Rahardiansah, Trubus P., Pengantar Ilmu Politik: Paradigma, Konsep Dasar dan Relevansinya untuk Ilmu Hukum, Jakarta: Universitas Trisakti, 2006.

Romli, Lili, Problematik Institusionalisasi Partai Politik di Era Reformasi, Jakarta: LIPI, 2017.

\section{B. Surat Kabar dan Sumber Online}

Danang Firmanto, Terbongkarnya Saracen Diklaim Tekan Konten Negatif, dalam Koran Tempo, 6 September 2017.

Ikhsanuddin, Jokowi Demokrasi Kita Sudah Kebablasan, dalam http://nasional.kompas.com/read/2017/02/22/12031291/jokowi.demokrasi.ki ta.sudah.kebablasan, (diakses tanggal 10 September 2017).

Martin Sihombing, Jokowi Minta Kobarkan Terus Semangat Memperkuat Pancasila, dalam http://kabar24.bisnis.com/read/20170722/15/673935/jokowi-mintakobarkan-terus-semangat-memperkuat-pancasila, (diakses tanggal 10 September 2017).

Syailendra Wisnu, Pengakuan Agama Konghucu di Indonesia, dalam http://wisnu. blog.uns.ac.id/2011/03/10/pengakuan-agama-khonghucu-di-indonesia/, (diakses tanggal 10 September 2017).

Tyas Nisa Fadilah, Pluralisme Budaya dalam National Building di Indonesia, dalam http://www.kompasiana.com/tnfinspiratif/pluralisme-budaya-dalam-nationbuildingdiindonesia_552a7327f17e 61210fd623af, (diakses tanggal 09 September 2017).

Yanu Endar Prasetyo, Demokrasi Digital, dalam http://www.mediaindonesia.com/ index.php/news/read/73975/demokrasi-digital/2016-10-26\#, (diakses tanggal 10 September 2017).

\section{Wawancara}

Erna Ermawati Choatim, dosen Sosiologi di Universitas Nasional (Unas), Rabu 12 April 2017, Jakarta. 